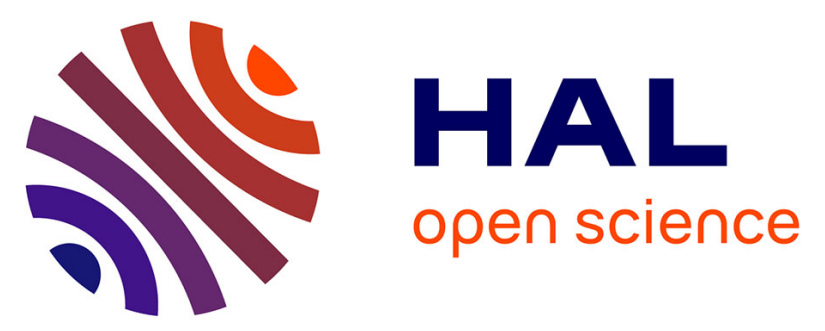

\title{
Antimicrobial properties against Aeromonas hydrophila and immunostimulant effect on Clarias gariepinus of Piper betle, Psidium guajava, and Tithonia diversifolia plants
}

Nunak Nafiqoh, S. Sukenda, Muhammad Zairin Junior, A. Alimuddin, Angela

Maria Lusiastuti, Samira Sarter, Domenico Caruso, Jean-Christophe Avarre

\section{To cite this version:}

Nunak Nafiqoh, S. Sukenda, Muhammad Zairin Junior, A. Alimuddin, Angela Maria Lusiastuti, et al.. Antimicrobial properties against Aeromonas hydrophila and immunostimulant effect on Clarias gariepinus of Piper betle, Psidium guajava, and Tithonia diversifolia plants. Aquaculture International, 2020, 28 (1), pp.1-13. 10.1007/s10499-019-00439-6 . hal-02921646

\section{HAL Id: hal-02921646 \\ https://hal.science/hal-02921646}

Submitted on 26 Aug 2020

HAL is a multi-disciplinary open access archive for the deposit and dissemination of scientific research documents, whether they are published or not. The documents may come from teaching and research institutions in France or abroad, or from public or private research centers.
L'archive ouverte pluridisciplinaire HAL, est destinée au dépôt et à la diffusion de documents scientifiques de niveau recherche, publiés ou non, émanant des établissements d'enseignement et de recherche français ou étrangers, des laboratoires publics ou privés. 
Antimicrobial properties against Aeromonas hydrophila and immunostimulant effect on Clarias gariepinus of Piper betle, Psidium guajava and Tithonia diversifolia plants

Nunak Nafiqoh ${ }^{1}$, Sukenda ${ }^{2}$, M. Zairin $\mathrm{Jr}^{2}$, Alimudin $^{2}$, Angela Lusiastuti ${ }^{1}$, Samira Sarter ${ }^{3}$, Domenico Caruso $^{3}$, Jean-Christophe Avarre ${ }^{3 *}$

${ }^{1}$ Research Institute for Freshwater Aquaculture and Fisheries Extension, Bogor, Indonesia ${ }^{2}$ Bogor Agriculture University, Bogor, Indonesia

${ }^{3} I S E M, I R D, C I R A D, C N R S$, EPHE, University of Montpellier, Montpellier, France

\section{*Corresponding author}

Jean-Christophe Avarre

Institut des Sciences de 1'Evolution de Montpellier

University of Montpellier, Place Eugène Bataillon, cc065

34095 Montpellier cedex 5, France

$+33467143748$

jean-christophe.avarre@ird.fr

ORCID 0000-0001-6899-7052 


\begin{abstract}
Aquaculture of the African catfish Clarias gariepinus has rapidly increased in South-East Asia over recent years, which has now become one of the most cultivated species. This culture intensification has resulted in the development of various diseases, among which the Motile Aeromonas Septicaemia (MAS) caused by Aeromonas hydrophila. The present study aimed at investigating the potential of three plants, Piper betle, Psidium guajava and Tithonia diversifolia, to prevent this disease using an enriched fish diet during four weeks. Though the minimum inhibitory and bactericidal concentrations of acetone-extracts were relatively high (2-32 $\mathrm{mg} \mathrm{mL}^{-1}$ and 8-64 mg mL $\mathrm{mL}^{-1}$, respectively), all 3 plant powders imbedded in feed significantly reduced fish mortalities following an experimental infection with A. hydrophila, as indicated by relative percent survivals (RPS) ranging from $77 \%$ to $79 \%$. When used in combination, the 3 plant extracts showed no interaction in vitro. Even though they improved RPS in comparison with controls, they were, however, less efficient in reducing mortalities than single plants. None of the plant-enriched diet had a clear effect on blood cell count or on reactive oxygen species (ROS) production (except for $P$. betle, which significantly increased ROS production after infection); however, both individual plants and their combinations significantly limited the drop of haematocrit following infection. Altogether, these results indicate that selection of plants for herbal therapy is complex and might depend on several in vivo criteria, and as such should not solely rely upon measurement of their antimicrobial activity.
\end{abstract}

Key-words: Clarias, Motile Aeromonas Septicaemia, plants, antimicrobial properties 


\section{Introduction}

Aquaculture provides nearly half of the fish consumed in the world, and developing countries account for $61 \%$ of the world's traded sea food (Fao 2018). Diseases of aquatic animals are considered as a severe threat to the sustainability of aquaculture, as they jeopardize the efforts and outcomes of millions of small fish farmers throughout the world. Global outbreaks in aquaculture contribute to the loss of several billion US dollars per year (Assefa and Abunna 2018).

Aquaculture intensification over the world has often been associated with a considerable use of antibiotics, widely recognized for their adverse effects on the environment microbial ecosystems, as well as on public and animal health. Antimicrobial resistance has been reported in both European and tropical aquaculture, not only in pathogenic bacteria, but also in commensal and environmental isolates (Cabello et al. 2013). Moreover, resistant bacteria or their resistance genes may spread among the aquatic communities, which in turn may enter human food chain (Chen et al. 2015).

Eco-friendly alternatives for therapeutic and prophylactic purposes in health management of aquatic animals are therefore of high priority, as they meet both environmental and societal demands (a high sanitary quality of seafood products). In this regard, the use of plants may provide an eco-friendly solution for the development of a sustainable health management of fish farms. There is growing scientific evidence about the beneficial effects of diets enriched with plant extracts or natural compounds on fish health and prevention of disease outbreaks (Reverter et al. 2014). The active molecules contained in plants (such as alkaloids, terpenoids, saponins and flavonoids) may provide inhibitory activity against pathogenic microorganisms, without eliciting bacterial resistance as is often the case with antibiotics (Chandra et al. 2017). For these reasons, plants may be considered as a promising alternative to the use of chemo-therapeutants, particularly antibiotics (Wink 2015). However, the effectiveness of plant extracts used as antimicrobial depends on many factors linked to their chemical composition, the hydrophobicity of bacteria tested, the exposure time and bacterial cell concentration (Patra and Mohanta 2014). On the other hand, the use of plant combinations may increase their effectiveness through synergistic effects ( $\mathrm{Ji}$ et al. 2007). Finally, in addition to their potential antibacterial activity, plant extracts may improve the non-specific immunity of several cultured fish, as well as the digestibility and availability of nutrients, thereby resulting in an increase in feed conversion efficiency and protein synthesis (Talpur and Ikhwanuddin 2013). 
Although the use of plants in freshwater aquaculture is widespread in Indonesia, the reasons for their choice by the farmers should be developed further. A comprehensive ethno-botanic survey carried out in West Java revealed that improvement of water quality and disease management were the major drivers (63\% of cases) of plant use (Caruso et al. 2013). This study also highlighted that Clarias spp. farming was strongly associated with the use of local plants. In addition to their frequent usage by fish farmers, the three plants investigated in the present study (Piper betle, Psidium guajava and Tithonia diversifolia) display antibacterial activity against Aeromonas hydrophila (Caruso et al. 2016; Muniruzzaman and Chowdhury 2004), and may therefore be useful for preventing fish infection by this major pathogen in tropical regions.

Clarias gariepinus was introduced to Indonesia in the early 1980s and its culture quickly expanded to the whole country. Like other members of this genus (e.g. C. batrachus), it is easy to breed and can grow in most aquaculture systems; as such, it has become a popular food source to fulfil protein needs in several developing countries, including Indonesia, where it is now the second bred freshwater species with a production of more than $1 \mathrm{M}$ tons $\mathrm{y}^{-1}$ (Pouomogne 2019). Due to its low oxygen demand, C. gariepinus is often cultured in high density, which favors the development of various diseases, among which the Motile Aeromonas Septicaemia (MAS) caused by Aeromonas hydrophila and may cause around 70$90 \%$ mortality during an outbreak (Hanson et al. 2014). The most common symptoms associated with MAS disease are loss of appetite, sores around the mouth, skin haemorrhages and lesions. As in other countries, this bacterial disease is mostly treated in Indonesia with antibiotics such as penicilline, oxytetracycline or ciprofloxacin (Sukarni et al. 2012). In order to promote an ecological alternative to antibiotics against MAS in Clarias aquaculture, the present study aimed at investigating the antibacterial activities, hematological and immunostimulant effects of three plants widely used by fish farmers: Piper betle, Psidium guajava and Tithonia diversifolia. Leaves of the 3 plants were tested alone and in combination, both for their in vitro and in vivo activity.

62

\section{Materials and methods}

\section{Plant extractions}

The plants were all purchased as leaf powder from the Indonesian Spices and Medicinal Crops Research Institute (ISMERI) and selected due to their wide availability in Indonesia and frequent use as medicinal purpose both for humans and animals. Extracts were obtained 
from these plants using a maceration method because of its simplicity and low cost. For maceration, one part of plant leave powder was immersed in 10 parts of acetone $(\mathrm{g} / \mathrm{v})$ as the best solvent described by Eloff (1998), incubated for 24 hours at room temperature in an orbital shaker $(50 \mathrm{rpm})$ and then filtered through Whatmann $\left(\mathrm{N}^{\circ} 41\right)$ paper filters. Filtered solutions were then evaporated by rotary evaporation (Heidolph WB 200) at $40^{\circ} \mathrm{C}$ and $60 \mathrm{rpm}$ until complete solvent removal. The resulting plant extracts were stored in dark glass bottles at $4^{\circ} \mathrm{C}$ until use.

\section{MIC and MBC tests}

Each of the three plant extracts was tested against the Gram negative Aeromonas hydrophila fish pathogenic bacteria to determine its ability to inhibit bacterial growth in vitro. The bacterial strain used in this study was isolated from a diseased catfish (Clarias sp.) by the fish health management laboratory, Research Institute of Freshwater Aquaculture and Extension Fisheries, West Java, Indonesia. To confirm its pathogenicity, it was reinjected into a healthy C. gariepinus and collected after the appearance of clinical signs, twice consecutively. It was then identified as Aeromonas hydrophila with the kit API 20 NE (BioMérieux) and archived at $-80^{\circ} \mathrm{C}$ in $20 \%$ glycerol. For the present assays, the strain was thawed, passaged 4 times on liquid medium and tested again twice on catfish as described above. It was incubated overnight in Mueller Hinton Broth (MHB) medium (Himedia) at $30^{\circ} \mathrm{C}$, such that the optical density at $630 \mathrm{~nm}$ was around 0.08 to 0.09 , corresponding to $10^{7} \mathrm{CFU} \mathrm{mL}^{-1}$. Serial 1:2 dilutions of plant extracts, from $64 \mathrm{mg} \mathrm{mL}^{-1}$ to $0.031 \mathrm{mg} \mathrm{mL}^{-1}$, were prepared in water supplemented with $1 \%$ DMSO. Using 96-microwell plate, $20 \mu \mathrm{L}$ of each diluted plant extract were mixed with $20 \mu \mathrm{L}$ of the bacterial suspension and $160 \mu \mathrm{L}$ of MHB, and incubated overnight at $30^{\circ} \mathrm{C}$. Controls consisted of either $20 \mu \mathrm{L}$ of bacterial suspension and $180 \mu \mathrm{l}$ of MHB (positive control), $200 \mu \mathrm{L}$ of MHB alone (negative control) or $20 \mu \mathrm{L}$ of plant extract and $180 \mu \mathrm{L}$ MHB (extract control as a blank). Each control was tested in triplicate and each dilution was tested in 4 replicates. Optical density was measured after $24 \mathrm{~h}$ of incubation, and the lowest concentration of plant extract that inhibit the bacterial growth was determined as the minimum inhibitory concentration (MIC). To measure the minimum bactericidal concentration (MBC), full loops of the culture were striked onto MHA plates (Mueller Hinton Agar) and incubated overnight at $30^{\circ} \mathrm{C}$. The MBC was determined as the lowest concentration that did not show any colony growth after sub-culturing (Fankam et al. 2015).

\section{Bacterial growth interaction tests}


103 To test a potential synergistic effect between the three plant extracts, two combinations with 104 varying proportions were tested: combination 1 (C1) contained an equal amount of each plant extract (33\%), whereas combination 2 (C2) was based on the individual MIC values that were measured for each plant, and contained $19 \%$ of P. guajava, 5\% of P. betle and $76 \%$ of $T$. diversifolia. $\mathrm{MIC}$ and $\mathrm{MBC}$ tests for plant extract combinations were determined as describe above. The fractional inhibitory concentration (FIC), defined as the ratio between the MIC of the test sample in combination and the MIC of the sample used alone, were calculated for each plant combination. FIC index, which corresponds to the sum of fractional inhibitory concentrations, was calculated following Shafiei et al. (2016), and determined the interactions among the plant extracts:

$$
\sum F I C=(F I C I+F I C I I+F I C I I I)
$$

It was defined as synergistic when $\sum$ FIC $\leq 1$, antagonistic when $\sum$ FIC $\geq 4$, or non-interactive when $1<\sum$ FIC $<4$ (van Vuuren and Viljoen 2011).

\section{Experimental fish, feeding trials and bacterial challenge}

118 Juvenile fish Clarias gariepinus $(7 \pm 0.6 \mathrm{~cm}$ and $3.2 \pm 0.8 \mathrm{~g})$ were purchased from local fish 119 farmer, placed in $30 \mathrm{~L}$ aquaria (30 fish / aquarium) filled with room temperature water (28$\left.12030^{\circ} \mathrm{C}\right)$ and treated with $\mathrm{NaCl}(10 \mathrm{ppm})$ for 3 days after arrival. They were acclimated to such 121 laboratory conditions for two weeks during which they were fed ad libitum with commercial 122 diet (Chaoroen Phokpand Prima Indonesia), and during which their health status was frequently checked by visual inspection. Fish were treated according to Indonesian regulations, and all experiments were carried out under the accreditation SNI 7583:2010. Fish were split into six experimental groups: one group for each individual plant ( $P$. guajava, $P$. betle and T. diversifolia groups), two groups corresponding to the 2 combinations ( $\mathrm{C} 1$ and $\mathrm{C} 2$ groups) and 1 control group. Each group comprised three replicates consisting of 20 fish reared in a single $30 \mathrm{~L}$ aquarium.

129 For the feeding trials, the same commercial feed as above was ground and mixed with plant 130 powder. For single plant treatments, $80 \mathrm{~g}$ of leave powder were mixed to $1 \mathrm{~kg}$ of grinded 131 pellets supplemented with $1 \%$ of carboxymethylcellulose as binder. Three hundred $\mathrm{mL}$ of water were added to this mix, which were then repelleted. For $\mathrm{C} 1$ and $\mathrm{C} 2$ treatments, the same proportions of dry leaves as used in in vitro combination tests were applied. Fish of the control group were fed with dry pellets without plant supplementation. Fish from all groups 
were fed with the experimental diet for four weeks, twice daily, representing $\sim 5 \%$ of biomass. Every 3 days, $40-50 \%$ of water was renewed.

\section{In vivo challenge test}

139 For the challenge test, A. hydrophila was grown in Tryptic Soy Broth (TSB) medium 140 overnight at $30^{\circ} \mathrm{C}$. The actual bacterial concentration was determined by measuring the 141 optical density at $630 \mathrm{~nm}$ (as described above) and confirmed by colony counting. The 142 culture was diluted in Phosphate Buffer Saline (PBS) to obtain a concentration of $10^{7} \mathrm{CFU}$ $143 \mathrm{~mL}^{-1}$. One hundred $\mu \mathrm{L}$ of diluted culture were intramuscularly injected into the dorsal part of 144 the fish at the end of the 4-week feeding trial. During the challenge, fish continued to receive the same experimental diet, and mortality was recorded two times per day for 10 days.

\section{Blood sampling procedure}

148 Five fish from each treatment group were sampled at the beginning (day 1) and at the end of 149 the feeding period (day 28) as well as 24 hours post-challenge. Approximately $200 \mu \mathrm{L}$ of 150 blood were withdrawn from the caudal vein of each individual fish with a $1 \mathrm{~mL}$ syringe. The withdrawn blood was treated as follow: one drop was smeared onto a microscope slide for leucocyte differentiation, $10 \mu \mathrm{L}$ were injected into a heparinized microhaematocrit capillary tube, whereas the remainder was mixed with $\mathrm{Na}$-citrate $(3.8 \%)$ as anticoagulant for reactive oxygen species measurement.

\section{Measurement of haematological and innate immunity parameters}

157 Reactive oxygen species (ROS) production was measured by quantifying the reduction of nitroblue tetrazolium into formazan, following the protocol described by Biller-Takahashi et al. (2013), except that blood was incubated at $27^{\circ} \mathrm{C}$ instead of $25^{\circ} \mathrm{C}$. Haematocrit percentage

160 was measured according to Sirimanapong et al. (2014). For leukocyte differentiation, the

161 smeared blood was air dried, stained with Giemsa and observed under microscope with 162 1000x magnification assisted with immersion oil. One hundred leukocytes were counted and 163 percentage of neutrophils, monocytes and lymphocytes was then calculated according to Adel et al. (2015).

\section{Statistical analyses}


167 Normality and equal variance of data where checked using Shapiro-Wilk test and Brown-

168 Forsythe test, respectively. When both criteria were respected, a one-way Anova followed by

169 a post hoc test (Holm-Sidak method) was applied to evaluate the effect of the different herbal

170 treatments; otherwise, a Kruskal-Wallis one-way Anova on Ranks was used. These analyses

171 were used to study the effect of the different herbal treatments on blood parameters between

172 the last day of feeding trial (day 28, before infection) and 1 day after A. hydrophila infection.

173 Comparison before infection and after infection within each treatment group was carried out 174 using a t-test. Mortalities resulting from the experimental infection were compared with Chi 175 square followed by a Kaplan-Meier survival analysis and post hoc analysis using Holm176 Sidak method. Differences between treatments were considered significant when $\mathrm{P}<0.05$. 177 Relative Percent Survival (RPS) was calculated according to Amend (1981) as follows:

178 Relative percent survival $=1-\frac{\text { (\% of treated group })}{(\% \text { of control group })} \times 100$.

179

180 Results

181

182 Antimicrobial activity

183 The minimum inhibitory concentrations and minimum bactericidal concentrations were 184 measured for the three plant extracts against the pathogenic bacteria A. hydrophila. Overall, $185 P$. betle extracts showed the highest ability to inhibit bacterial growth, with MIC and MBC of 1862 and $8 \mathrm{mg} \mathrm{mL}^{-1}$, respectively. P. guajava and T. diversifolia displayed higher MIC (8 and 32 $187 \mathrm{mg} \mathrm{mL} L^{-1}$, respectively) and $\mathrm{MBC}\left(64 \mathrm{mg} \mathrm{mL}^{-1}\right.$ each) values (Table 1). The FIC index of 188 tested combinations among the 3 plant extracts indicated the absence of antagonistic or 189 synergistic effect between them.

190

191 Fish growth during feeding trials

192 After replacement of the regular feed by the experimental diet, fish from all groups stopped 193 eating. Whereas control fish recovered appetite after 2 days, fish from the other treatment 194 groups started to eat again after 3 days only. Body weight of each fish was measured every 7 195 days during the feeding trial. After one week of experimental diet, the average weight was 196 comparable in all groups, ranging from $2.90 \pm 0.21 \mathrm{~g}$ ( $P$. betle group) to $3.49 \pm 0.17 \mathrm{~g}$ (C2 197 group). After 4 weeks, however, fish from the control group displayed a significantly higher $198(\mathrm{P}<0.05)$ body weight $(7.00 \pm 0.57 \mathrm{~g})$ than those from all the other treatment groups $(3.56 \pm$ 
$1990.27 \mathrm{~g}$ for $P$. betle group to $5.14 \pm 0.39 \mathrm{~g}$ for $P$. guajava group). Moreover, no visible change 200 in vigour/health was observed in any group following administration of the experimental diet.

\section{Haematological and immune parameters}

203 Since almost no significant difference was found between day 1 and day 28 , figures will only

204 illustrate the differences before and after experimental infection.

205 After 4 weeks of feeding, there were no differences in haematocrit values, except for fish fed with $P$. betle, which had a significantly lower haematocrit than control animals (Anova on Rank $\mathrm{P}=0.009$ ). After infection, haematocrit was significantly lower in survivor fish of control group than in fish fed with T. diversifolia leaves (One way Anova, $\mathrm{P}=0.03$ ) (Fig.1). Most notably, infection had no significant effect on the haematocrit of the treated groups, whereas it significantly decreased that of the control group (t-test, $\mathrm{P}<0.001$ ) (Fig 1).

211 Likewise, there was no variation in blood cell count after 4 weeks of herbal administration,

212 except in fish fed with $T$. divesifolia, which showed the highest percentage of monocytes; 213 however this difference was significant (one way Anova, $\mathrm{P}=0.021$ ) only compared to group

214 C1 (not shown). Following experimental infection, significant variations in blood cell count 215 were observed in survivors of all groups; notably with a marked neutrophilia, monocytosis 216 and lymphocytopenia (Fig. 2). However, none of these modifications could be ascribed to 217 herbal treatment and no difference was observed with the control group in all three categories 218 of blood cells.

219 Reactive oxygen production, reflected by NBT test, showed no significant difference after 4 weeks between the different herbal treatments and the control (Anova on Rank, $\mathrm{P}=0.161$ ). Following infection, NBT increased for all treatments, including the control; however, this increase was significantly higher in fish fed with $P$. betle than in the control animals (Fig. 3 ).

\section{Experimental infection}

225 Clinical signs of all moribund and dying fish consisted of red sores, skin ulcers, internal hemorrhages and hemorrhagic ascites, compliant with an infection by A. hydrophila. Data of cumulative mortality and RPS are summarized in Table 2. Chi-square analysis revealed a significant difference between treatments (78.631 with 5 degrees of freedom, $\mathrm{P}=<0.001$ ). The highest cumulative mortality was observed in the control group (83.6\%). All mortalities occurred during the first 7 days post-infection (Fig. 4). Except for fish fed with C1 combination, mortalities were significantly lower in all other herbal treatments. Survival analysis (Fig. 4) showed that best survival rates were obtained in fish fed with individual 
233 plants, and in a lesser extent with C2 combination. No synergistic effect on survival was 234 observed when the three plants were administrated together, compared to single plant treatments.

\section{Discussion}

238 The aim of the present work was to evaluate the effect of three plants against MAS, caused 239 by Aeromonas hydrophila, by testing both in vitro and in vivo approaches in Clarias 240 gariepinus. MIC values of the 3 plants were all above $1 \mathrm{mg} \mathrm{mL}^{-1}$. Even though a compound that displays a MIC value higher than $100 \mu \mathrm{g} \mathrm{mL}^{-1}$ has been reported to have a low antibacterial activity (Kuete 2010), it is worth noticing that this threshold concerns isolated compounds of plants and might vary depending on the methods used, which are not standardized in the literature for plant extracts. For crude extracts, this threshold might be too high, as attested by our study and other published work (Bussmann et al. 2010). The ability of plant extracts to inhibit bacterial growth indicates that some of their natural compounds have antimicrobial properties. P. betle main active compounds belong to phenylpropene class, which includes eugenol, chavicol or chavibetol (Bajpai et al. 2010). In contrast, Tithonia diversifolia and Psidium guajava share a number of common compounds, such as $\alpha$-pinene, $\beta$-pinene, germacrene $D$ and $\beta$-caryophyllene, though at different percentages (Rajan and Thenmozhi 2015; Wanzala et al. 2016). These natural compounds may have various effects against different bacteria, depending on their biochemical characteristics. The common modes of action of plant extracts against bacteria are not specific, and include for instance increased cell permeability, cytotoxicity, gene silencing, cell filamentation, membrane disruption, genomic DNA binding etc. (He et al. 2018; Wink 2015). The high survival rates obtained on treated fish after the bacterial challenge tend to indicate that the in vitro properties of a plant are not directly correlated with its in vivo effects, as was already reported (Anusha et al. 2014). Under these conditions, selection of active plants should not solely rely upon measurement of their MIC. A recent review highlighted that all antimicrobial tests carried out in vitro are difficult to reproduce in clinical trials, and may have a limited predictive value (Mundy et al. 2016). In spite of this, in vitro antimicrobial tests remain essential in the evaluation of potential antimicrobial candidates, mainly because they do not require the sacrifice of animals. However, additional information, such as ethnobotanical data or comparative usage in human or veterinary pharmacopeia, is likely to help the discovery of efficacious plants for fish. 
266 Application of combined plants may be considered as an alternative way for preventing 267 diseases. It is indeed acknowledged that the combination of two or more plants will provide a better performance of plants as medicine (Che et al. 2013). For illustration, the use of four herbs in combination significantly increased the survival of red seabream juveniles compared to single herb application ( $\mathrm{Ji}$ et al. 2007). In the present study, the three individual plant extracts significantly reduced the mortality caused by A. hydrophila. However, when used in combination, their efficiency was lower, as indicated by higher RPS values. Interestingly, the two combinations used in vivo led to significantly different survival rates, suggesting that the proportion of each active compound in the diet is an important factor to consider. A previous study on the combination of $P$. betle with $P$. guajava and Andrographis paniculata showed an ability to prevent MAS infection caused by A. hydrophila on Clarias sp. when supplemented to fish diet (Wahjuningrum et al. 2007). In this study, the combination 0.25:0.75:1 elicited the best survival rate compared to other combinations. In herbal therapy, complex interactions may appear when plants are formulated together with varying proportions. An example of unwanted interaction between herbs is the presence of tannins. These substances may hinder the absorption of proteins and alkaloids, or induce enzymes such as cytochrome P450, which may in turn accelerate drug catabolism and result in blood levels of active substances that are too low to elicit a therapeutic effect (Williamson 2001). Surprisingly, growth of herbal-treated fish was lower than that of control animals. As already reported (Bulfon et al. 2015), the impact of plants on fish growth may greatly vary. The reduced growth that was observed after herbal treatment could be linked to the presence of antinutritional compounds, or more simply to a loss of feed palatability that resulted in a reduced feed intake. Though additional studies are needed to address this loss of growth, the lower weight of animals fed with plants did not prevent their beneficial effect against $A$. hydrophila infection. These results suggest that such herbal treatments should not be used as 291 long-term diets.

292 Nitroblue tetrazolium assay, which measures the reactive oxygen species (ROS) produced by 293 phagocytic cells, is a good indicator of phagocytic activity in fish (Biller-Takahashi et al. 2013). An increase in ROS production was observed in all fish groups only after the bacterial challenge, and this increase was significantly higher in animals treated with $P$. betle compared to controls. Concomitantly, the proportion of neutrophils and leucocytes also increased after infection, yet in the same manner for all treatments. However, none of the plant extracts tested here had a direct effect on ROS production before infection, as was observed with date palm extract applied to European seabass (Guardiola et al. 2016) or with 
different herbs and spices administered to the tilapia Oreochromis mossambicus (Gültepe et al. 2014), and in contrast with the oral administration of Eclipta alca to O. mossambicus, where ROS production increased after one week post-feeding, although fish were not challenged with any pathogen (Christybapita et al. 2007). Haemolysis is retained as a key factor of A. hydrophila virulence (Gonzáles-Serrano et al. 2002). As a consequence of infection, a drop of red blood cell counts was observed in the control fish, and in a lesser extent in the $\mathrm{C} 1$ group. However, the fact that haematocrit of all treated fish did not significantly change after bacterial infection suggests that the addition of plants in the diet contributed to prevent blood cell lysis during infection. These results are in good agreement with the survival rates measured after infection, and indicate that leave powder of these plants may inhibit, at least partially, the haemolytic activity of A. hydrophila or prevent red blood cell from haemolysis.

312 To conclude, in spite of contrasted MIC values, the 3 species of plants tested in this study showed a high and nearly identical efficiency in reducing the mortality due to an infection with A. hydrophila. Although the two tested combinations had no antagonistic interaction in vitro and elicited higher survival rates than controls, they were less efficient in reducing mortalities than the individual plants. In order to get better insights into the beneficial use of these plants, additional combinations leading to synergistic interactions should be searched and tested for their ability to increase survival rates.

\section{Acknowledgements}

Nunak Nafiqoh benefited from an IRD fellowship under the BEST program. We are thankful to the Indonesian Ministry of Fisheries and Marine Affairs for providing PhD scholarship to Mrs. Nafiqoh as well as experimental facilities. This is publication ISEM-DIVA-XXX.

\section{Compliance with Ethical Standards}

The authors declare that they have no conflict of interest. ). All experiments involving fish complied with animal welfare and were carried out under the Indonesian accreditation SNI 7583:2010.

\section{References}

Adel M, Abedian Amiri A, Zorriehzahra J, Nematolahi A, Esteban Mn (2015) Effects of dietary peppermint (Mentha piperita) on growth performance, chemical body composition and hematological and immune parameters of fry Caspian white fish 
(Rutilus frisii kutum) Fish Shellfish Immunol 45:841-847. https://doi.org/10.1016/j.fsi.2015.06.010

Amend DF (1981) Potency testing of fish vaccines. International Symposium in Fish Biologics: Serodiagnostics and Vaccines. Dev Biol Stand 49:447-454

Anusha P, Thangaviji V, Velmurugan S, Michaelbabu M, Citarasu T (2014) Protection of ornamental goldfish Carassius auratus against Aeromonas hydrophila by treating Ixora coccinea active principles. Fish Shellfish Immunol 36:485-493. https://doi.org/10.1016/j.fsi.2013.12.006

Assefa A, Abunna F (2018) Maintenance of fish health in aquaculture: Review of epidemiological approaches for prevention and control of infectious disease of fish. Vet Med International 2018:1-10. https://doi.org/10.1155/2018/5432497

Cabello FC, Godfrey HP, Tomova A, Ivanova L, Dölz H, Millanao A, Buschmann AH (2013) Antimicrobial use in aquaculture re-examined: Its relevance to antimicrobial resistance and to animal and human health. Environ Microbiol 15:1917-1942. https://doi.org/10.1111/1462-2920.12134

Caruso D, Lusiastuti AM, Slembrouck J, Komarudin O, Legendre M (2013) Traditional pharmacopeia in small scale freshwater fish farms in West Java, Indonesia : An ethnoveterinary approach. Aquaculture 416-417:334-345. https://doi.org/10.1016/j.aquaculture.2013.09.048

Caruso D, Lusiastuti AM, Taukhid T, Avarre J-C, Yuhana M, Sarter S (2016) Ethnobotanical uses and antimicrobial properties of plants in small-scale tropical fish farms: The case 
of Indonesian fish farmers in Java (Indonesia). $\mathrm{J}$ World Aquacult Soc. https://doi.org/10.1111/jwas.12345

Chandra H, Bishnoi P, Yadav A, Patni B, Mishra AP, Nautiyal dAR (2017) Antimicrobial resistance and the alternative resources with special emphasis on plant-based antimicrobials-A Review. Plants 6:11. https://doi.org/10.3390/plants6020016

Che CT, Wang ZJ, Sing M, Chow S, Wai C, Lam K (2013) Herb-herb combination for therapeutic enhancement and advancement: Theory, practice and future perspectives. Molecules 18:5125-5141. https://doi.org/10.3390/molecules18055125

Chen $\mathrm{H}$ et al. (2015) Antibiotics in typical marine aquaculture farms surrounding Hailing Island, South China: Occurrence, bioaccumulation and human dietary exposure. Mar Pollut Bull 90:181-187. https://doi.org/10.1016/j.marpolbul.2014.10.053

Eloff JN (1998) Which extractant should be used for the screening and isolation of antimicrobial components from plants ? J Ethnopharmacol 60:1-8. https://doi.org/10.1016/S0378-8741(97)00123-2

Fankam AG, Kuiate JR, Kuete V (2015) Antibacterial and antibiotic resistance modifying activity of the extracts from Allanblackia gabonensis, Combretum molle and Gladiolus quartinianus against Gram-negative bacteria including multi-drug resistant phenotypes. BMC Complement Altern Med 15:1-12. https://doi.org/10.1186/s12906015-0726-0

Fao (2018) The state of world fisheries and aquaculture 2018 - Meeting the sustainable development goals. FAO. http://www.fao.org/documents/card/en/c/I9540EN. Accessed 1 July 2019

Gonzáles-Serrano CJ, Santos JA, Garcí-Lopéz M-L, Otero A (2002) Virulence markers in Aeromonas hydrophila and Aeromonas veronii biovar sobria isolates from freshwater fish and from a diarrhoea case. J Appl Microbiol 93:414-419. https://doi.org/10.1046/j.1365-2672.2002.01705.x

Guardiola FA, Porcino C, Cerezuela R, Cuesta A, Faggio C, Esteban MA (2016) Impact of date palm fruits extracts and probiotic enriched diet on antioxidant status, innate immune response and immune-related gene expression of European seabass 
400

401

402

403

404

405

406

407

408

409

410

411

412

413

414

415

416

417

418

419

420

421

422

423

424

425

426

427

428

429

430

431

432

(Dicentrarchus labrax). Fish Shellfish Immunol 52:298-308. https://doi.org/10.1016/j.fsi.2016.03.152

Gültepe N, Bilen S, Y1lmaz S, Güroy D, Aydın S (2014) Effects of herbs and spice on health status of tilapia (Oreochromis mossambicus) challenged with Streptococcus iniae. Acta Vet Brno 83:129-136. https://doi.org/10.2754/avb201483020000

Hanson LA, Liles MR, Hossain MJ, Griffin MJ, Hemstreet WG (2014) Motile Aeromonas Septicemia. In: Fish Health Section Blue Book: suggested procedures for the detection and identification of certain finfish and shellfish pathogens., vol 1.2.9. 2014 edn. AFS-FHS, Bethesda, Maryland, pp 1-11

He T-F, Zhang Z-H, Zeng X-A, Wang L-H, Brennan CS (2018) Determination of membrane disruption and genomic DNA binding of cinnamaldehyde to Escherichia coli by use of microbiological and spectroscopic techniques. J Photochem Photobiol B-Biol 178:623-630

Ji SC, Takaoka O, Jeong GS, Lee SW, Ishimaru K, Seoka M, Takii K (2007) Dietary medicinal herbs improve growth and some non-specific immunity of red sea bream Pagrus major. Fish Sci 73:63-69. https://doi.org/10.1111/j.1444-2906.2007.01302.x

Kuete V (2010) Potential of Cameroonian plants and derived products against microbial infections : A review. Planta Med:1479-1491

Mundy L, Pendry B, Rahman M (2016) Antimicrobial resistance and synergy in herbal medicine. J Herb Med 6:53-58. https://doi.org/10.1016/j.hermed.2016.03.001

Muniruzzaman M, Chowdhury MBR (2004) Sensitivity of fish pathogenic bacteria to various medicinal herbs. Bangl J Vet Med 2:75-84

Patra JK, Mohanta YK (2014) Antimicrobial compounds from mangrove plants: A pharmaceutical prospective. Chin J Integr Med 20:311-320. https://doi.org/10.1007/s11655-014-1747-0

Pouomogne V (2019) Cultured Aquatic Species Information Programme. Clarias gariepinus. FAO. http://www.fao.org/fishery/culturedspecies/Clarias_gariepinus/en. Accessed 1 July 2019

Rajan S, Thenmozhi S (2015) GC-MS analysis of bioactive compounds in Psidium guajava leaves. J Pharmacogn Phytochem 3:162-166

Reverter M, Bontemps N, Lecchini D, Banaigs B, Sasal P (2014) Use of plant extracts in fish aquaculture as an alternative to chemotherapy: Current status and future perspectives. Aquaculture 433:50-61. https://doi.org/10.1016/j.aquaculture.2014.05.048 
Shafiei Z, Haji Abdul Rahim Z, Philip K, Thurairajah N (2016) Antibacterial and antiadherence effects of a plant extract mixture (PEM) and its individual constituent extracts (Psidium sp., Mangifera sp., and Mentha sp.) on single- and dual-species biofilms. PeerJ 4:e2519-e2519. https://doi.org/10.7717/peerj.2519

Sirimanapong W, Thompson KD, Kledmanee K, Thaijongrak P, Collet B, Ooi EL, Adams A (2014) Optimisation and standardisation of functional immune assays for striped catfish (Pangasianodon hypophthalmus) to compare their immune response to live and heat killed Aeromonas hydrophila as models of infection and vaccination. Fish Shellfish Immunol 40:374-383. https://doi.org/10.1016/j.fsi.2014.07.021

Sukarni, Maftuch, Nursya H (2012) Kajian penggunaan ciprofloxacin terhadap histologi insang dan hati ikan botia (Botia macracanthus, Bleeker) yang diinfeksi bakteri Aeromonas hydrophila. J Exp Life Sci 2:6-12

Talpur AD, Ikhwanuddin M (2013) Azadirachta indica (neem) leaf dietary effects on the immunity response and disease resistance of Asian seabass, Lates calcarifer challenged with Vibrio harveyi. Fish Shellfish Immunol 34:254-264. https://doi.org/10.1016/j.fsi.2012.11.003

van Vuuren S, Viljoen A (2011) Plant-based antimicrobial studies - Methods and approaches to study the interaction between natural products. Planta Med 77:1168-1182. https://doi.org/10.1055/s-0030-1250736

Wahjuningrum D, Tarono, Angka SL (2007) Efficacy of Andrographis paniculata, Psidium guajava and Piper betle as prevention on Motile Aeromonad Septicaemia infection in African catfish (Clarias sp.). J Akuakultur Indonesia 6:127-133

Wanzala W, Osundwa EM, Alwala J, Gakuubi MM (2016) Chemical composition of essential oil of Tithonia diversifolia (Hemsl.) A. Gray from the Southern slopes of Mount Elgon in Western Kenya. IJEPP 2:72-83

Williamson EM (2001) Synergy and other interactions in phytomedicines. Phytomedicine 8:401-409

Wink M (2015) Modes of action of herbal medicines and plant secondary metabolites. Medicines 2:251-286. https://doi.org/10.3390/medicines2030251 
463 Table 1. MIC, MBC and FIC index for the three plant extracts and their combination tested 464 against A. hydrophila

\begin{tabular}{lllll}
\hline & P. betle & P. guajava & T. diversifolia & $\sum \mathrm{FIC}$ \\
\hline MIC $\left(\mathrm{mg} \mathrm{mL}^{-1}\right)$ & 2 & 8 & 32 & \\
MBC $\left(\mathrm{mg} \mathrm{mL}^{-1}\right)$ & 8 & 64 & 64 & \\
FIC for C1 $\left(\mathrm{mg} \mathrm{mL}^{-1}\right)$ & 2 & 0.5 & 0.125 & 2.625 \\
FIC for C2 $\left(\mathrm{mg} \mathrm{mL}^{-1}\right)$ & 2 & 0.5 & 0.125 & 2.625
\end{tabular}

465

466

467

468

469

470

Table 2. Cumulative mortality rate, expressed as $\% \pm \mathrm{CI}(\alpha=0.05)$, and relative percent

471 survival (RPS) of Clarias gariepinus according to herbal treatments following an

472

experimental infection with A. hydrophila $(\mathrm{N}=60)$

\begin{tabular}{llll}
\hline Treatment & $\%$ mortality & Confidence interval & RPS \\
\hline P. betle & $17.2 \%$ & $\pm 9.7 \%$ & $79 \%$ \\
P. guajava & $18.2 \%$ & $\pm 11.4 \%$ & $78 \%$ \\
T. diversifolia & $19.5 \%$ & $\pm 12.1 \%$ & $77 \%$ \\
C2 & $27.9 \%$ & $\pm 13.4 \%$ & $67 \%$ \\
C1 & $52.1 \%$ & $\pm 14.1 \%$ & $38 \%$ \\
Control & $83.6 \%$ & $\pm 9.8 \%$ & $0 \%$ \\
\hline
\end{tabular}

473

474

475 
476 Figure 1. Haematocrit, expressed as Mean $\% \pm \mathrm{SE}$, before and after infection $(\mathrm{N}=5)$.

477 Asterisks indicate significant differences with the respective control group at the same 478 treatment time, whilst double daggers indicate significant differences before and after 479 experimental infection.

480

481 Figure 2. Differential leucocyte count (\%) of Clarias gariepinus before and after infection. 482 The proportion of lymphocytes (A), neutrophils (B) and monocytes (C), expressed as a Mean $483 \pm \mathrm{SE}$, amounts 100\% (N=5). Except for control animals, each group of fish was fed for 4 484 weeks prior to infection with a diet enriched with plant extracts. Different letters indicate a 485 statistically significant difference $(\mathrm{P}<0.05)$.

486

487 Figure 3. Reactive oxygen production (Mean \pm SE) of Clarias gariepinus before and after 488 infection $(\mathrm{N}=5)$. Except for control animals, each group of fish was fed for 4 weeks prior to 489 infection with a diet enriched with plant extracts. Different letters indicate a statistically significant difference $(\mathrm{P}<0.05)$.

491

492 Figure 4. Kaplan-Meier Survival Analysis (N=60). Except for control animals, each group of 493 fish was fed for 4 weeks prior to infection with a diet enriched with plant extracts. Different 494 letters indicate a statistically significant difference $(\mathrm{P}<0.05)$.

495

496 
$497 \quad$ Figure 1

498

499

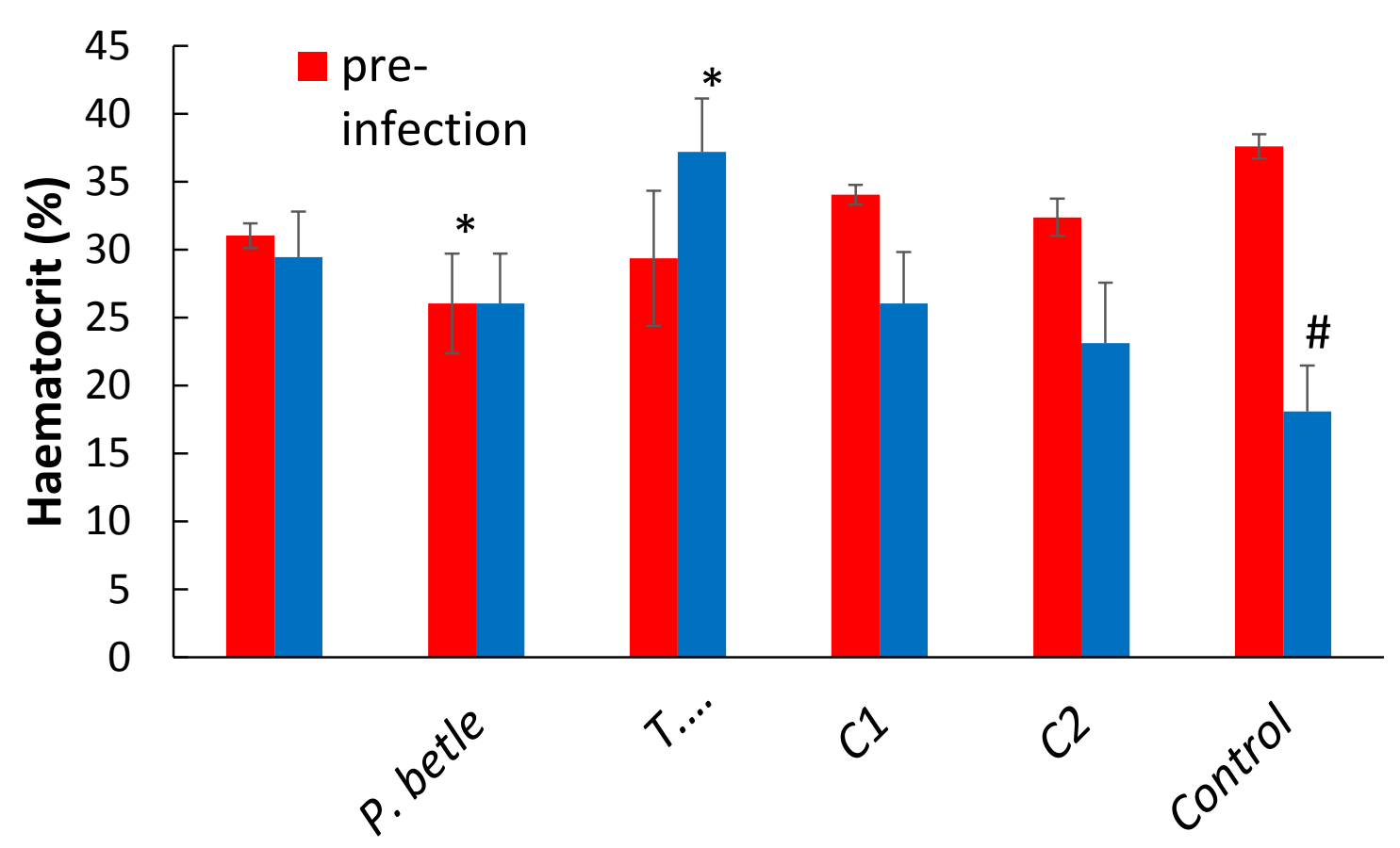




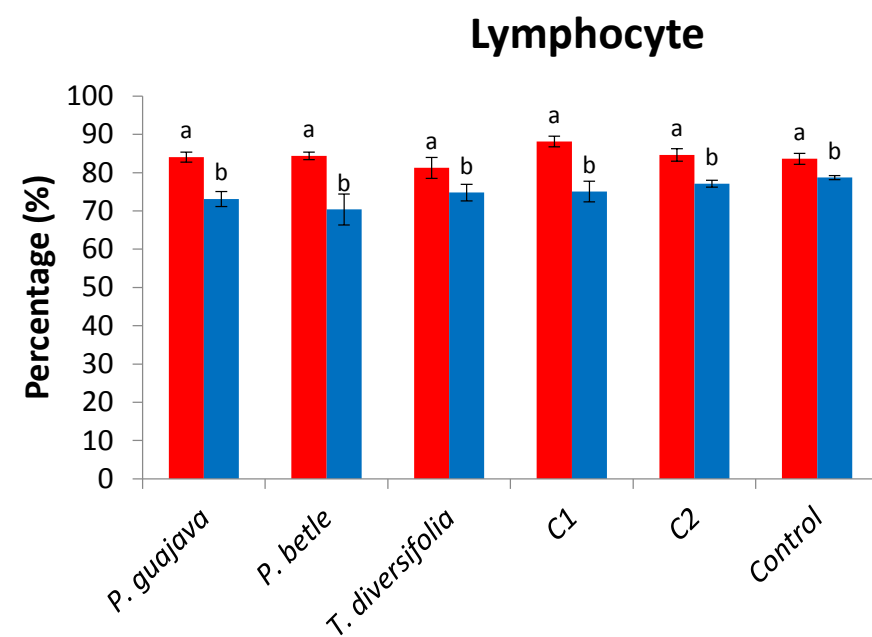

- pre-infection

- post-infection

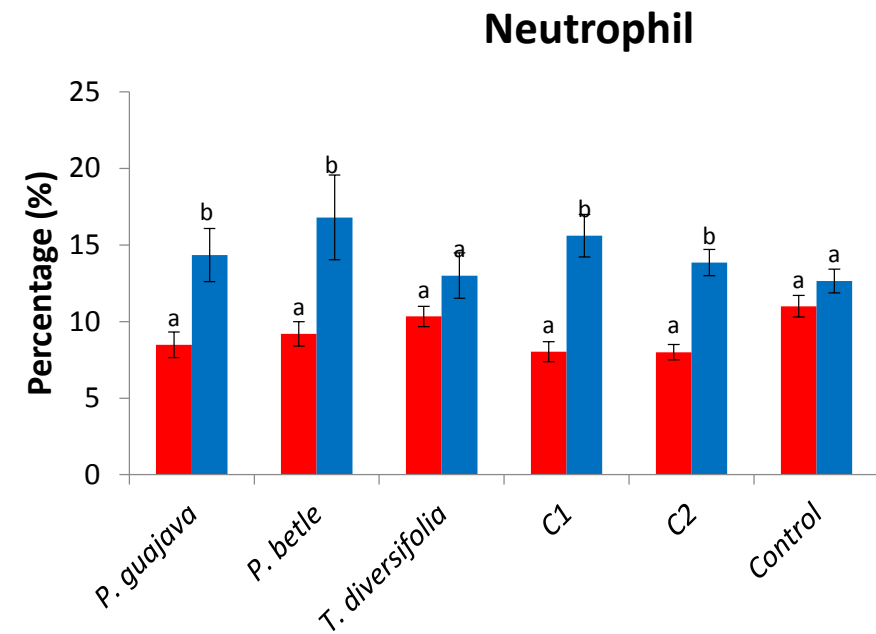

- pre-infection

a post-infection

Monocyte

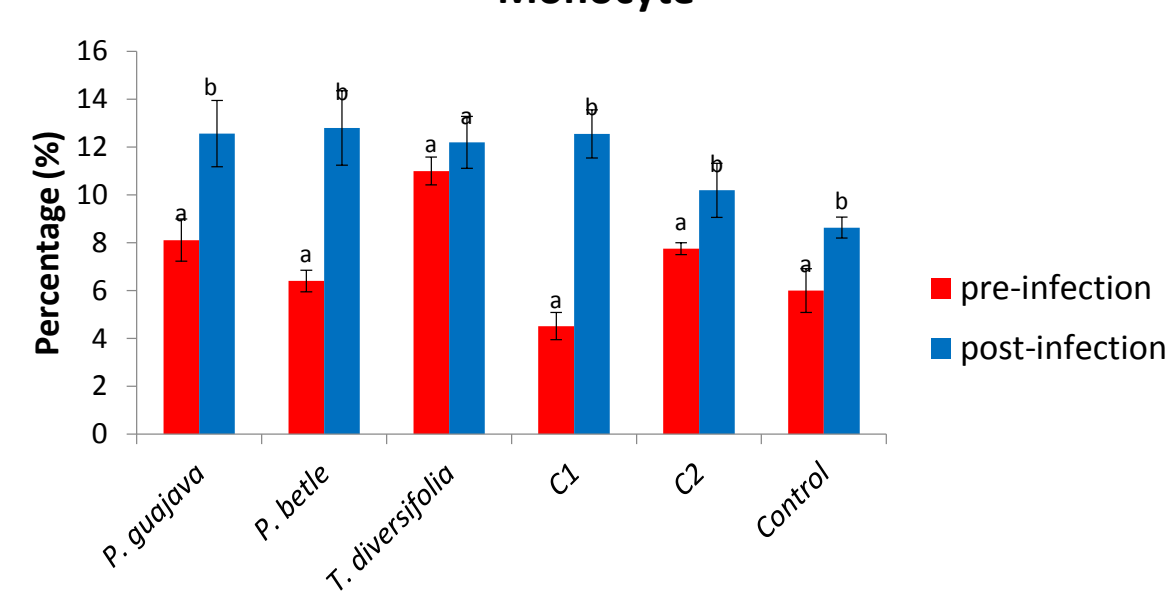


$502 \quad$ Figure 3

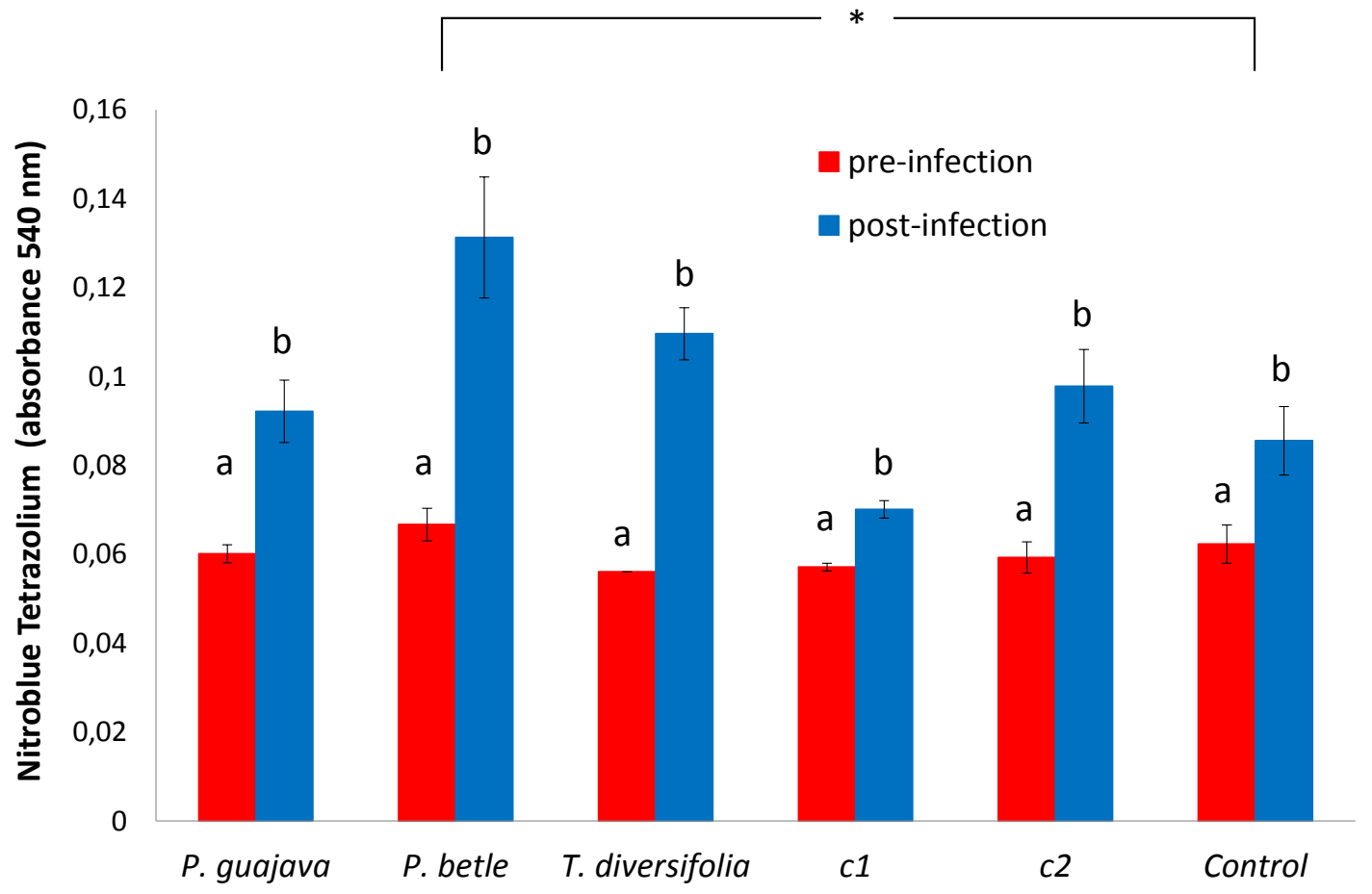

503

504 
$505 \quad$ Figure 4

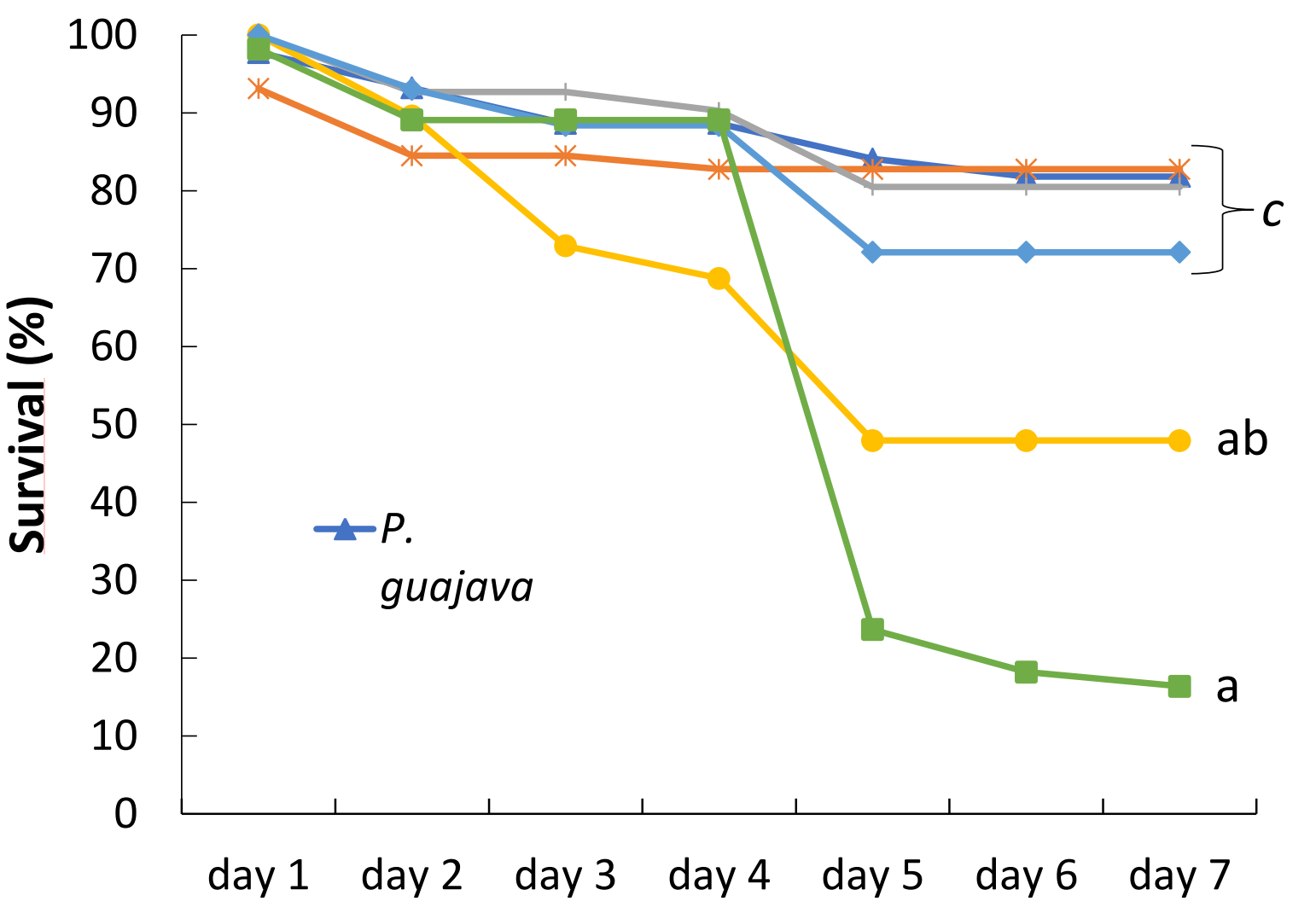

507 